\title{
Diocesan Licensing and Medical Practitioners in South-West England, 1660-1780
}

\author{
IAN MORTIMER*
}

\section{Introduction}

The licensing of provincial surgeons and physicians in the post-Restoration period has proved an awkward subject for medical historians. It has divided writers between those who regard the possession of a local licence as a mark of professionalism or proficiency, ${ }^{1}$ those who see the existence of diocesan licences as a mark of an essentially unregulated and decentralized trade, ${ }^{2}$ and those who discount the distinction of licensing in assessing medical expertise availability in a given region. ${ }^{3}$ Such a diversity of interpretations has meant that the very descriptors by which practitioners were known to their contemporaries (and are referred to by historians) have become fragmented and difficult to use without a specific context. As David Harley has pointed out in his study of licensed physicians in the north-west of England, "historians often define eighteenth-century physicians as men with medical degrees, thus ignoring ... the many licensed physicians throughout the country". ${ }^{4}$ One could similarly draw attention to the inadequacy of the word "surgeon" to cover licensed and unlicensed practitioners, barber-surgeons, Company members in towns, self-taught practitioners using surgical manuals, and procedural specialists whose work came under the umbrella of surgery, such as bonesetters, midwives and phlebotomists. Although such fragmentation of meaning reflects a diversity of practices carried on under the same occupational descriptors in early modern England, the result is an imprecise historical literature in which the importance of licensing, and especially local licensing, is either ignored as a delimiter or viewed as an inaccurate gauge of medical proficiency.

The exception to the above is the recent work on records relating to the licensing of midwives. Several scholars have recently attempted to explain more clearly the role of midwives, showing the relationships between licence applications and their clients'

* Ian Mortimer BA MA RMSA FRHistS, Department of History, University of Exeter. Address for correspondence: 43 Ford Street, Moretonhampstead, Devon TQ13 8LN, UK.

\footnotetext{
${ }^{1}$ For example, J H Raach, A directory of English country physicians, 1603-1643, London, Dawsons of Pall Mall, 1962; R M S McConaghey, 'The history of rural medical practice', in F N L Poynter (ed.), The evolution of medical practice in Britain, London, Pitman Medical Publishing, 1961, pp. 117-44.

${ }^{2}$ For example, Irvine Loudon, Medical care and the general practitioner, 1750-1850, Oxford, Clarendon Press, 1986.
}

${ }^{3}$ For example, Margaret Pelling and Charles Webster, 'Medical practitioners', in Charles Webster (ed.), Health, medicine and mortality in the sixteenth century, Cambridge University Press, 1979, pp. 165-236. The authors provide a basis for quantifying practioner/patient ratios, without breaking down those ratios into the more subtle strata of licensed practitioner/patient ratios.

${ }^{4}$ David Harley, “ "Bred up in the study of that faculty": licensed physicians in north-west England, 1660-1760', Med. Hist., 1994, 38: 398-420, p. 399. 


\section{Ian Mortimer}

support, their repeat business with known clients, the range in status of their clients, and the importance of their moral standing. ${ }^{5}$ With regard to ecclesiastical licensing, the important implication of this research is that it has involved a systematic re-evaluation of the records accompanying grants of licences, generally given the group name "testimonials", rather than an eclectic approach drawing upon one or two examples.

This article is an attempt to examine more closely the functions of the ecclesiastical licensing system in a provincial part of southern England. Through a detailed and systematic examination of the extant testimonials and Act Books of the diocese of Exeter, covering Devon and Cornwall and two parishes in Somerset, ${ }^{6}$ it aims to establish what purposes the system served to all parties concerned: patient, parishioner, practitioner and ecclesiastical official. As will be seen, this presents few constants. It does, however, permit a view of the multifaceted and changing importance of licensing in a geographically disparate but largely self-contained diocese, and its dramatic decline in the second quarter of the eighteenth century, and suggests reasons for these changes.

\section{Trends in Episcopal Licensing}

It is well known that episcopal licensing was introduced by legislation in the reign of Henry VIII. ${ }^{7}$ It is also well known that it remained the principal means of legally recognizing practitioners without the benefit of a university education for more than 250 years. ${ }^{8}$ For those with a degree it also served as a means of securing the approbation of an ecclesiastical authority for paid healing and medical advice. It is less widely known that it was a minority attribute; most non-university trained practitioners were not licensed by the diocesan authorities, and locally licensed practitioners dealt with a minority of cases. ${ }^{9}$ Only about 160 practitioners were licensed locally in the six decades 1661-1720. As the population of the two counties which make up the major part of the diocese in 1660 was in the region of $330,000,{ }^{10}$ this equates to

\footnotetext{
${ }^{5}$ Doreen Evenden, 'Mothers and their midwives in seventeenth-century London', David Harley, 'Provincial midwives in England: Lancashire and Cheshire, 1660-1760', and Ann Giardina Hess, 'Midwifery practice among the Quakers in southern rural England in the late seventeenth century', all in Hilary Marland (ed.), The art of midwifery, London, Routledge, 1993. D A Beaufort, 'The medical practitioners of western Sussex in the early modern period: a preliminary survey', Sussex Archaeological Collections, 1993, 131: 139-51. Doreen Evenden, The midwives of seventeenth-century London, Cambridge University Press, 2000. Adrian Wilson, A safe deliverance: childbirth in seventeenth-century England, London, UCL Press, 1998.

${ }^{6}$ These are the parishes of Bradford and Somerton, which were peculiars of the Bishop of Exeter. Chardstock, which is also included, is now in Somerset but in the early modern period was in Devon.

${ }^{7}$ See, for example, John R Guy, 'The episcopal licensing of physicians, surgeons and midwives', Bull.
}

Hist. Med., 1982, 56: 528- 42; R S Roberts, 'The personnel and practice of medicine in Tudor and Stuart England. Part 1: the provinces', Med. Hist., 1962, 6: 363-82.

${ }^{8}$ Technically the legislation granting bishops the right to license practitioners was not repealed until 1948. See Guy, op. cit., note 7 above, p. 542.

${ }^{9}$ It was not purely at a local level that one could be licensed. The universities, the Archbishop of Canterbury, other ecclesiastical authorities and the Privy Council could all license a physician or surgeon. Records relating to diocesan licensing should therefore not be taken to reflect all licensed practitioners, nor should they be seen as wholly representative of medical activities in a particular vicinity.

${ }^{10}$ Jonathan Barry, 'Population distribution and growth in the early modern period', in Roger Kain and William Ravenhill (eds), Historical atlas of south-west England, Exeter University Press, 1999, pp. 116-17, on p. 116. 


\section{Diocesan Licensing and Medical Practitioners}

approximately one licensed practitioner per 5,000 population every thirty years, a fraction of the overall practitioner/patient ratios of 1:200 noted for Norwich and 1:400 noted for London and rural East Anglia by Margaret Pelling and Charles Webster in the late sixteenth century. ${ }^{11}$ The ratio of licensed practitioners in Devon and Cornwall was hardly any greater when the system was at its peak, in the period 1610-40, when only 86 diocesan licences were granted, and only about 250 are known to have been issued in total between 1610-1774. ${ }^{12}$ Given these numbers it is unlikely that more than 80 locally licensed practitioners were practising at any one time in the diocese.

To go beyond this point, and to use the extant records quantitatively to establish patterns of application, grant, remit, refusal and types of qualification reflected in the records of licensing is problematic. The difficulties arise largely from doubts about the completeness of the records; even the series of bound registers or Act Books that purport to contain a complete record of "all the acts expedited in the Principal Registry" are known to be lacking entries. Five extant applications for licences carry codicils referring to grants not recorded in the Act Books. ${ }^{13}$ The Subscription Books cannot be used as a check since these are not extant for some crucial periods. ${ }^{14}$ While a degree of human error may be acknowledged to be present in all recording work, and more or less constant, other forms of human error are not, or at least cannot be presumed to be constant. For example, the failure of a record clerk to note grants of licences made away from Exeter at visitations may be counted a human error, but the frequency with which such an error was made depends very much on the regularity and thoroughness of visitations, and licences being granted at them. However, in this case the entries lacking in the Act Books do not appear to be connected to regular visitations or other events since they are not clustered about a particular time but fairly evenly spread. In addition, a further forty-five extant applications do have similar codicils referring to grants which tally with the Act Books, suggesting there was no particularly wayward period in the institution's record keeping. The implication that there is an approximate 10 per cent under-recording rate should be borne in mind when considering the figures in Table $1 .{ }^{15}$

\footnotetext{
${ }^{11}$ Pelling and Webster, op. cit., note 3 above, pp. 227, 233.

${ }^{12}$ Devon Record Office, Exeter (hereafter DRO): Chanter 42-49; Roberts, op. cit., note 7 above, p. 369; McConaghey, op. cit., note 1 above, p. 129. In addition, 38 were granted in the period 1568-97. The Act Book for the years $1597-1610$ is only extant in a few fragments. McConaghey's figure of 288 grants is difficult to account for; it is suspected that he listed all the applications he found as well as all licence grants recorded.

${ }^{13}$ These are the applications of Peter Classen, surgeon, of Exeter, 1665; Thomas Bryant, surgeon, of Endellion, 1717; Joseph Hemminge, physician and surgeon of Liskeard, 1723; William Gayer, surgeon of Okehampton, 1731, and John Palfreman, physician and surgeon of Molland, 1783.

${ }^{14}$ DRO: Chanter 151-167. The missing volumes include the period 1682-91. Also the problems are compounded by the fact that no single subscription
}

\footnotetext{
book was authoritative, and various volumes overlap. The Act Books are thus considered more authoritative, despite their lacunae.

${ }^{15}$ DRO: Chanter 41-49 (Diocesan Act Books, 1568-97, 1610-46, 1661-1734). These are continued by separate registers of grants for the period after 1734, in Chanter 87 and 88. Where available, the Act books' indexes, compiled by Mr Chanter, were used (1568-97; 1610-78). Two of the fifty licences granted noted by Chanter in his indexes were not found, although a thorough search was made. One was due to his failure to note the page number, and another due to the illegibility of the page number in his index. One entry not indexed by Chanter was found. It is unlikely that a great many entries were missed by Chanter: thirty pages were scrutinized to check his indexing. His greatest failing was palaeography, misreading several names. All entries found and used here were newly transcribed.
} 


\section{Ian Mortimer}

Table 1

Grants of licences as recorded in the Act Books of the diocese of Exeter, 1661-1783

\begin{tabular}{lcccccccc}
\hline Date & Physic & Surgery & $\begin{array}{c}\text { Surgery \& } \\
\text { pharmacy }\end{array}$ & $\begin{array}{c}\text { Physic \& } \\
\text { surgery }\end{array}$ & Midwifery & Other & Total & $\begin{array}{c}\text { Rate per } \\
\text { year }\end{array}$ \\
\hline $1661-1675$ & 16 & 21 & 0 & 9 & 0 & 0 & 46 & 3.0 \\
$1676-1690$ & 13 & 17 & 0 & 3 & 6 & 0 & 39 & 2.6 \\
$1691-1705$ & 6 & 16 & 0 & 13 & 1 & 0 & 36 & 2.4 \\
$1706-1720$ & 3 & 26 & 0 & $6^{1}$ & 3 & $2^{2}$ & 40 & 2.7 \\
$1721-1735$ & 1 & 3 & 0 & 7 & 0 & 0 & 11 & 0.7 \\
$1736-1750$ & 0 & 7 & $11^{3}$ & 1 & 0 & 0 & 19 & 1.3 \\
$1751-1765$ & 2 & 4 & $4^{4}$ & 6 & 1 & 0 & 17 & 1.1 \\
$1766-1780$ & 0 & 0 & $4^{5}$ & $2^{6}$ & 1 & 0 & 7 & 0.5 \\
$1781-1795$ & 0 & 0 & 0 & 1 & 0 & 0 & 1 & 0.1 \\
Total & 41 & 94 & 19 & 48 & 12 & 2 & 216 & $1.8^{7}$ \\
\hline
\end{tabular}

${ }^{1}$ Including one licence for "physic, surgery and pharmacy" in 1715 .

${ }^{2}$ Licence granted for "Curing the Ricketts" in 1712, and for bonesetting in 1708.

${ }^{3}$ Includes 6 licensed as a "Surgeon, apothecary and man-midwife".

${ }^{4}$ Includes 1 licensed as a "Surgeon, apothecary and man-midwife".

${ }^{5}$ Includes 4 licensed as a "Surgeon, apothecary and man-midwife".

${ }^{6}$ Both licensed for "Physic, surgery and man-midwifery".

${ }^{7}$ This figure is the mean for the dates 1661-1783, the latter being the date of the last licence granted.

These figures illustrate a number of trends. First, there is a shift in practitioners' nomenclature, from the strict adherence to "physic" and/or "surgery" in the 1660s to combinations of descriptions more in line with the great preponderance of "surgeonapothecaries" noted by Joan Lane in her study of the 1783 edition of the Medical Register. ${ }^{16}$ Second, there is a paucity of licences granted for midwifery, in great contrast to London, where Doreen Evenden has consulted "hundreds" of applications and grants. ${ }^{17}$ With an average of only one licence per decade, the system was clearly of little importance as a means of supervising midwives in Devon and Cornwall, and it would appear from the extant applications that very few midwives even applied. But the most notable feature is the rate of grants, and especially the overall decline of licences after 1718. All but one of the eleven licences recorded as granted in the period 1719-35 date from 1723-24 (the exception is dated 1731), and only five were conferred between 1738-47. Moreover this small number was not due to a general lack of activity in the diocesan registry; the number of schoolmasters' licences in the period 1725-30 was maintained at a high level, approximately two-thirds of that of the 1690s. In effect there is evidence of a collapse rather than a decline of the medical licensing system in

\footnotetext{
${ }^{16}$ Joan Lane, 'The medical practitioners of provincial England in 1783', Med. Hist., 1984, 28: 353-71.
}

\footnotetext{
${ }^{17}$ Evenden, 'Mothers and their midwives', op. cit., note 5 above, p. 9.
} 


\section{Diocesan Licensing and Medical Practitioners}

1718-19, followed by a minor resurgence in the period 1747-61, and another minor resurgence $1767-74 .{ }^{18}$

These figures are also significant for a reconsideration of the importance of dates which historians have regarded as pivotal in the history of provincial medical control. The comparatively high level of licensing at the beginning of the period is particularly noticeable. Indeed, one might say that in the diocese of Exeter the system was at its height immediately after the Restoration, in a seemingly determined move to return to the pre-Commonwealth situation. Notwithstanding the fact that no licences had been available since 1646, and that therefore the increase after 1660 should be understood in the context of stifled demand, the figures easily bear comparison with totals for earlier decades. More detailed inspection reveals that most of this demand was indeed immediately after the Restoration: 30 licences were granted in the period $1663-75$, a rate of 2.3 per year; but in the immediate postRestoration period $1661-62$ at least 15 grants were made ( 7.5 per year). ${ }^{19}$ Similarly close examination of the grants around 1687-88, when the College of Physicians attempted to impose control on all the dioceses by insisting that only physicians examined in London should be licensed, ${ }^{20}$ reveals the effect in the region. In the period 1678-87, 30 licences were given; none were granted in the year after the receipt of the letter (1688), and only 15 licences were recorded in the period 1689-97. On the strength of this evidence one might postulate that the College of Physicians dealt a significant blow to the medical licensing system in the south-west.

It is one thing to say the system was at its height in the early 1660 s based upon numbers of licences issued and quite another to claim it was also performing at its peak in terms of efficiency and quality of assessment of candidates. Margaret Pelling has identified the regime of Archbishop Laud in the 1630s as the "most rigorous" period of medical licensing, especially for midwives. ${ }^{21}$ Unfortunately, it is not possible to say whether this was the case in the diocese of Exeter since no applications for licences survive from before $1660 .^{22}$ But for the period 1660-1780 a number of applications do survive, although not all, and thus some assessment of the thoroughness with which the system was operating in the south-west may be attempted.

There are testimonials and letters relating to 209 applications or appeals for help in the years $1661-1783 .^{23}$ Needless to say, these documents do not closely correspond with the 216 recorded grants in the same period. There are 71 recorded grants for which no testimonial is present, and 58 applications or related documents for which no licence appears to

\footnotetext{
${ }^{18}$ David Harley has noticed a similar rise in the 1750s for Lancashire and Cheshire, and attributed it to the rise of man-midwifery and practitioners' need to justify "their expanding practices". It may also have acted as a religious safeguard of their intrusion into what was traditionally seen as women's affairs. See Harley, op. cit., note 5 above, pp. 38-9.

${ }^{19}$ By comparison, in the diocese in 1568-97, 38 applications were recorded as being granted to 35 individuals (some were granted only temporarily), an unadjusted rate of 1.3 per year. In $1610-27$, 50 were granted (2.8 per year) and in $1628-41,36$ were granted (2.6 per year). DRO, Chanter 41-43.
}

\footnotetext{
${ }^{20}$ Harley, op. cit., note 4 above, p. 401.

${ }^{21}$ Margaret Pelling, The common lot: sickness, medical occupations and the urban poor in early modern England, London, Longman, 1998, p. 33.

${ }^{22}$ There is one exception to this: a certificate of competence dated 1659 whose bearer, Abraham Haward, obtained his licence in 1665 after obtaining a second certificate. The 1659 certificate is discussed later.

${ }^{23}$ DRO: Moger II, 'surgeons' licences'. This total includes letters relating to applications but does not include multiple documents relating to a single application.
} 


\section{Ian Mortimer}

Table 2

Applications for licences in the diocese of Exeter, 1661-1783

\begin{tabular}{|c|c|c|c|}
\hline Date $^{1}$ & $\begin{array}{l}\text { No. of extant } \\
\text { applications } \\
\text { (a) }\end{array}$ & $\begin{array}{c}\text { Number of extant } \\
\text { applications } \\
\text { granted (b) }\end{array}$ & $\begin{array}{l}\text { Proportion } \\
\text { successful } \\
\text { (b/a) }\end{array}$ \\
\hline $1661-1675$ & 54 & 29 & $54 \%$ \\
\hline $1676-1690$ & 11 & 5 & $45 \%$ \\
\hline $1691-1705$ & 42 & 29 & $69 \%$ \\
\hline $1706-1720$ & 39 & 32 & $82 \%$ \\
\hline $1721-1735$ & 13 & 10 & $77 \%$ \\
\hline $1736-1750$ & 20 & 17 & $85 \%$ \\
\hline $1751-1765$ & 17 & 17 & $100 \%$ \\
\hline $1766-1780$ & 6 & 6 & $100 \%$ \\
\hline 1783 & 1 & 1 & $100 \%$ \\
\hline Total & $203^{2}$ & 142 & mean $=70 \%$ \\
\hline
\end{tabular}

${ }^{1}$ Undated documents have been dated by the date of the grant to which they relate, or, in the few cases where this has not been possible, by the mid-point of a date range suggested by other data, for example, the period of office of the bishop to whose authority the document was submitted, the reign or the king, or a period established by the names of signatories (where these are other practitioners, clergymen or mayors).

${ }^{2}$ This table does not include the 1659 certificate for Thomas Harward, made before the licensing system was restored.

have been granted. However, the most important question is not how many testimonials survive but how representative is the extant series. As far as can be judged, the series is random. Certain dates are lacking, such as the January 1663 to August 1665 period, and 1675-86, but these are wholly absent, and do not represent any bias other than temporal. There is no sign of any geographic bias. Approximately one-quarter of the extant documents relate to each of the four archdeaconries (Cornwall, Barnstaple, Totnes and Exeter). There is no indication that only successful applications were kept, nor that certain types of practitioners' application were kept more than any other, and no evidence that only certain types of "difficult case" were retained for future reference. While there are very few relating to women, this is also reflected in the evidence of the grants in the Act Books. Although no doubt a number of applications were made which are no longer extant, and it is of course possible that there was an increasing tendency to preserve only successful applications, an examination of the surviving testimonials in relation to each other and to the Act Books reveals a definite trend.

As far as can be gauged from the existing testimonials, the proportion of successful applications increased steadily between 1660 and 1760. Unless all unsuccessful applications were disposed of after $c .1750$, applicants during the mid-eighteenth century "revival" of licensing in the south-west were almost guaranteed their licence, revealing either a looser control of practitioners or a better quality of application. The latter of these might relate to more knowledgeable applicants or more appropriate applications, as some types of application were more acceptable than others, as will be discussed later. 


\section{Diocesan Licensing and Medical Practitioners}

Table 3

Proportion of licences granted with diocesan remit

\begin{tabular}{lccc}
\hline Date & $\begin{array}{c}\text { No. of grants with } \\
\text { known remit }\end{array}$ & $\begin{array}{c}\text { No. with diocesan } \\
\text { remit }\end{array}$ & $\begin{array}{c}\text { Proportion } \\
\text { diocesan }\end{array}$ \\
\hline $1661-1675$ & 36 (of 46) & 19 & $53 \%$ \\
$1676-1690$ & 25 (of 39) & 6 & $24 \%$ \\
$1691-1705$ & 13 (of 36) & 5 & $38 \%$ \\
$1706-1720$ & 28 (of 39) & 8 & $29 \%$ \\
$1721-1735$ & 8 (of 9) & 8 & $100 \%$ \\
$1736-1750$ & 8 (of 19) & 8 & $100 \%$ \\
$1751-1765$ & 10 (of 17) & 10 & $100 \%$ \\
$1766-1780$ & 3 (of 7) & 3 & $100 \%$
\end{tabular}

Episcopal licences could be issued for a range of geographical areas: for the whole diocese, for Devon only, Cornwall only, or for the vicinity of a single town or city. A number of factors may have influenced this: first, the applicant himself could have paid a higher fee for a diocese-wide licence rather than a county-wide one (although no applications state area of jurisdiction for which the practitioner was applying). The method of application also may have had a bearing on the geographical area of the licence, locally supported practitioners being only locally licensed, although, if this were the case, one has to ask why towns were very rarely specified as areas in which to practise (in only 5 cases out of 135 is the remit specified), and why intermediate jurisdictions, such as archdeaconries, were never specified. Finally, it is possible that status had a bearing on the area; it seems that holders of degrees and most "gentlemen" were licensed to practise throughout the diocese. This runs parallel to the suggestion that the weakening system was less discriminating in the post-1718 period than before; after that date very few practitioners were refused a licence, and invariably they were permitted to operate throughout the whole diocese.

If there was a hierarchical aspect to the geographical remit, and a diocese-wide licence reflected a lower level of control than a local licence, it could be argued that the late seventeenth century was the period of strictest control of practitioners. In this sense "control" is to be distinguished from the "rigour" of the College of Physicians in supervising the granting of licences in the 1630s, but it may have had as great an effect. In the last quarter of the seventeenth century there seems to have been an attempt to limit the areas in which licensed practitioners might operate. This is probably not attributable to practitioners themselves choosing not to pay for a diocesan licence, for in no application did any practitioner apply for a licence only to practise in a single county, or a single town, in the way that some applied only to perform a single type of cure. Furthermore, before 1641 the proportion of those receiving a licence to operate throughout the diocese was regularly in excess of 70 per cent (in the period 1568-97 it was 87 per cent). If the change in remit normally granted in the early eighteenth century is interpreted as a slackening of ecclesiastical control, or a greater deference by the church authorities to medical expertise, the second half of the seventeenth century should be seen as the period of greatest restrictions on 


\section{Ian Mortimer}

geographical freedom to practice, possibly in reaction to increasing numbers of itinerant practitioners.

To conclude this examination of trends in the system, it is possible to say that medical licensing in the diocese of Exeter underwent significant changes on at least two occasions, after the intervention of the College of Physicians in 1688, and about the years 1718-20. The first of these probably damaged the credibility of the system, albeit only temporarily. The 1718-20 changes were much more profound and permanent. Before then, an average of about three practitioners per year had applied for a licence, and a significant proportion, perhaps 40 per cent, had been turned down; and licentiates had been permitted to practise only in their own county or locality. After 1718 the numbers applying dropped. Licences were granted to most of those who applied after this date, and they did so increasingly on the strength of their peers' approval, and were permitted to describe themselves by composite titles such as "surgeon, apothecary and man-midwife", which previously had not been allowed. They were also given leave to practise throughout the whole diocese. It would appear standards were adapted-if not lowered - to prevent the complete collapse of the system. A brief revival took place in the 1740s. This was possibly an attempt by the ecclesiastical authorities to prop up their rights, either against or alongside the new medical authority created by the opening of the Devon and Exeter Hospital in 1741, or perhaps in order to help establish man-midwifery on a more moral footing; but this revival was over by 1761. Only a handful of licences were granted after this date.

\section{The Nature of an Episcopal Licence}

Since the only systematic studies of medical testimonials have been those relating to midwifery, it may be considered useful to take as a starting point one of the key findings relating to northern provincial midwifery licentiates, viz. that they "usually became licensed because they had been reported to a visitation as unlicensed". ${ }^{24}$ Certainly for the diocese of Exeter there is evidence that triennial bishop's visitations played a part in the licensing process. Five surgeons' licences were recorded in an Act Book as granted "during the Episcopal Visitation" of $1699,{ }^{25}$ and in 1677 one Mr Fox was "cited to appear at the visitation on Thursday next for practising Physic without a licence". ${ }^{26}$ But two key questions have to be answered. To what extent was this a punitive process, as opposed to a convenient time to present one's credentials? And how common was it for applications and grants to be submitted at or just after the visitation?

With regard to the first of these questions, there are few lists of presentments in the period for practising without a licence, ${ }^{27}$ and those for the seventeenth century exclusively relate to schoolmasters. ${ }^{28}$ However, the evidence of a few testimonials themselves may be used. The application of Richard Hanbury in 1692 asks that he be licensed by the bishop "at this his present visitation, that he may thereby be enabled farther to practise the said art". ${ }^{29}$ This

\footnotetext{
${ }^{24}$ Harley, op. cit., note 5 above, p. 30 .

${ }^{25}$ DRO: Chanter 47.

${ }^{26}$ DRO: Moger II/surgeons' licences/Devon/ Topsham.

${ }^{27}$ Call Books with wardens' presentments at visitations survive for Totnes and Exeter from 1744,
}

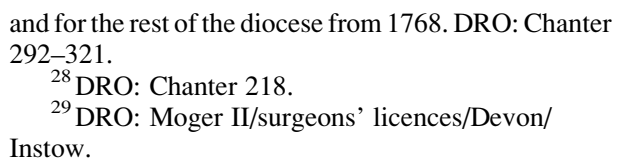




\section{Diocesan Licensing and Medical Practitioners}

document carries the signatures of two clergymen, neither of them the incumbent of the practitioner's own parish, and rather than being presented for acting without a licence in a punitive way, the indications are that he was being furnished with a letter of recommendation as a means of assisting him in his career, possibly enabling him to care for individuals in the parishes serviced by the signing incumbents. Although situations did arise at which a practitioner was presented for practising without a licence, as in the case of Mr Fox above, the role of the triennial visitation seems to have been relatively unimportant. Visitations in the diocese in the seventeenth century almost always took place in the months of August and September, the exception being November in the year 1662. In the period 1661-1701, there were 157 grants of a licence, of which 52 fell in a visitation year, showing no bias towards this as a means of successful licensing. A similar evaluation of extant testimonial dates shows that, in the period 1661-1701, 54 of the 96 applications were made in the same year as a visitation, and that 75 per cent of those made in a visitation year were made in the month immediately before, the month immediately after or the month of the visitation. However, when disregarding the abnormal year 1662, these figures shrink to 37 out of 74 applications (50 per cent). ${ }^{30}$ Thus one may conclude that while visitations at the end of the seventeenth century acted as a spur to practitioners to obtain a licence, they were not a hugely important factor. Up to three years was a long time to wait for a licence, and while some practitioners may have obtained one shortly after being presented, many who wanted a licence did not wait until the next visitation.

Whether in a visitation year or not, in most cases some form of testimonial was required for the aspiring licentiate. Scholars and archivists alike have rather lazily lumped all such documents under the single heading "testimonial" in the past, but in fact a great variety of documents were put forward in the favour of applicants. The most common of these, a certificate of competency, is referred to in a letter relating to the application of Thomas Bryant in 1717. Bryant sought the help of an influential friend, Mr W Dinham, to write to $\mathrm{Mr}$ Edward Cooke, the Diocesan Official, on his behalf. Dinham explains the procedure as he understood it:

[A surgeon's licence] I presume must come from your office, I presume he must get a certificate signed by two surgeons of his skill and of his being well-affected to the Present Gov't the forme of which Certificate I desire you to send me per return of post, and when that is sign'd and returned I presume you'l be able to send the licence without giving him the trouble of an Exeter journey ... ${ }^{31}$

Dinham seems to have been mistaken regarding the necessity of a visit, for a journey was undertaken. The next letter from Dinham reads: "The bearer (Mr Bryant) waits on you with his certificate signed by two skilful persons both well known to me soe that I hope we will meet with a Quicke despatch, upon his paying you the usual fees." The application in this case was granted ten weeks later. ${ }^{32}$

\footnotetext{
${ }^{30}$ The percentage of the year's applications falling in the months before, of, and after the visitation remains at 75 per cent.

${ }^{31}$ DRO: Moger II/surgeons' licences/Cornwall/ Endellion.

${ }^{32}$ This grant was not recorded in the Act Book. The length of time taken varied greatly. Jonathan Edwards' certificate was dated 8 November 1661 but his licence not granted until 17 September
}

the following year. Tubb Jewell's petition was dated 27 August 1668 in Bodmin and his licence granted within the week, on 3 September 1668. The delay with regard to Abraham Harward is noted later in the text. Six months passed between John Blight's certificate and licence in 1673. Three and a half months passed between Joshua Smith's petition and his licence in 1662. 


\section{Ian Mortimer}

Such applications as this, carrying the signatures of two known practitioners, were common, far more so than those signed by the four examiners required by the Act of 1511. ${ }^{33}$ Sixty-two of the 203 applications bear two signatures. Not all of these were the signatures of medical practitioners; a number of testimonials were signed by two clergymen, or one medical practitioner and one clergyman. Thirty-six testimonials bear three signatures, these most commonly being the names of a MD and two surgeons. Sixteen bear four signatures, and 33 per cent bear five or more. Two documents carry six medical men's signatures attesting to the proficiency of the applicant. Twenty per cent of documents have between eight and thirty-five signatures. The series of testimonials represents a wide range of approaches, from a letter to a communal petition.

Using the number and nature of the signatories as well as the texts, testimonials may be broken down into certain subgroups. First and most commonly, there is the certificate of competency that an applicant was "of sober life and conversation", "conformable to the law and doctrine of the Church of England", and "well-skilled in the art". This could be signed by two surgeons as above, or by a physician and two surgeons, or by a physician, clergyman and surgeons. The use of the three key phrases above was normal. Sometimes this certificate of competency is restricted to medical matters and accompanied by a separate testimonial to the "sober life" of the applicant, signed by a clergyman. The inclusion of both sorts of testimonial in several cases accentuates the differences between the two documents. ${ }^{34}$ Some degree of rule seems to have governed what was acceptable, at least on the combined sort of testimonial, since John Abbot wrote to the Diocesan Official in 1675 from Colyton:

I have got the draught of the certif[icate] which you sent me and have gotten 3 handes two ministers and one physition as for chirurgions we have never a one in our parts noe nearer than Exeter Sir I should desier you to give me a line or two in answer whether these are sufficient and when the Chancellor will be at home ${ }^{35}$

Similar in type to the above is the certificate of examination which was issued in a number of cases, normally signed by at least one MD, and sometimes three. At the other extreme are the petitions from communities for their practitioners to be given licences, often containing more than a dozen signatures. In between these there are personal petitions, signed only by the applicant or an acquaintance, and documents comparable with those which have provided the basis for the work on midwifery: certificates of skill signed by a number of patients (often the "customary" six noted by Evenden) attesting to the practitioner's skill with reference to particular medical acts. ${ }^{36}$ Quite common are composite testimonials, which include medical practitioners' names, the names of local clergymen and officers, and the names of patients cured by the practitioner in the past. The ten midwives'

${ }^{33}$ Statutes of the Realm, London, 1810-28, vol. 3, p. 31 (quoted in Lucinda Beier, Sufferers and Healers, Routledge \& Kegan Paul, 1987, pp. 12-13).

${ }^{34}$ A good example is that of Alexander Wolcott of Fowey. DRO: Moger II/surgeons' licences/Cornwall/ Fowey.

\footnotetext{
${ }^{35}$ DRO: Moger II/surgeons' licences/Devon/ Colyton.

${ }^{36}$ See Evenden, 'Mothers and their midwives', op. cit., note 5 above, p. 21. Examples include: DRO: Moger II/surgeons' licences/Devon/Sidmouth, Exeter (Edward Bury) and Honiton (Wm Richards).
} 


\section{Diocesan Licensing and Medical Practitioners}

testimonials also vary, one being signed by four women, others from the seventeenth century being signed by churchwardens and clergy, and mid-eighteenth-century ones by surgeons.

The wide range of testimonials can be reduced to two non-exclusive varieties: those which predominantly show a social need for a licence to be granted, and those which predominantly demonstrate a practitioner's medical competence and moral suitability. With regard to the latter, in cases where applicants were acquainted with a medical practitioner, it seems they obtained the relevant signatures and submitted a certificate of competency or combined testimonial. Where they had no well-known medical acquaintances on whom to rely for a certificate, they had to submit themselves to examination, at Exeter or a similar regional town, such as Plymouth or Liskeard. While it is difficult to distinguish between the certificates of competency signed in advance, and certificates of ability signed by the examining practitioners, several facts stand out. Supervising the examinations was a coterie of MDs, such as William Durston, Gray Holland, John Osmond, Thomas Pyne, Ellis Veryard, John Andrew, George Beal, Anthony Salter and Thomas Glass (to name only those most obviously acting in this capacity). In some documents they explicitly refer to examinations having taken place. The handful of candidates whom they each certified came from quite distinct regions, making it highly unlikely they knew them personally. ${ }^{37}$ Acting with these doctors was a group of licensed surgeons, such as James Briet, Richard Chilcott, and John Pearce, who also occasionally refer explicitly in their certificates to the fact that an examination has taken place. Where the candidate was applying for a licence in surgery, sometimes only surgeons were present at the examination. A good example is that of Noah Mahun:

Wee Chyrurgeons of the Citty of Exon doe hereby certifie to your Lord shipp that wee have strictly examined Mr Noah Mahun of St Endellion ... in the art of chirurgery, who wee finde fitt and qualified therein, and who deserves your Lordshipps lycence for the performing thereof $\ldots 1$ August 1709. [signed:] [Thomas] Downton surgeon. John Pearce surgeon. ${ }^{38}$

In other cases clergymen were also present, as in the examination of Joseph Hemminge, gent, and Nicholas Cary, gent, examined in physic and surgery, and surgery respectively, by Thomas Pyne MD, with the vicar of Menheniot, the vicar of Liskeard, and Benjamin Berry (a local surgeon) in July $1723 .^{39}$

While it is important not to assume that such examinations were particularly searching or of a comparable standard, there is evidence that examiners did discriminate against those who were felt to be insufficiently skilled. A detailed examination of the extant applications for licences to practise both physic and surgery compared with the arts for which the applicant was eventually licensed reveals that 16 such applicants (out of 52) were only

\footnotetext{
${ }^{37}$ For example, William Durston specifies examinations of candidates from Plymouth and Kingsbridge; Thomas Pyne and Ellis Veryard examined candidates from both Devon and Cornwall. John Osmond examined candidates from Crediton, Rewe, Aylesbeare and Bradninch.
}

\footnotetext{
${ }^{38}$ DRO: Moger II/surgeons' licences/Cornwall/ Endellion. This certificate of medical competence upon examination is accompanied by a character reference signed by five parish officials and two others.

${ }^{39}$ DRO: Moger II/surgeons' licences/Cornwall/ Liskeard.
} 


\section{Ian Mortimer}

granted part of their application: 9 were licensed only for surgery and 7 only for physic. In addition, a significant number of applications for licences to practise both arts have one or the other deleted in the certificate. The Latin certificates of competence upon examination note that candidates were examined in both theory and practice. In 1666 the examining doctors at Plymouth (William Durston and Gray Holland) wrote that "Johanem Fleming chirurgum examinatum fuisse coram nobis in re medica et compertum esse adeo peritum et puratum tum in theoris tum praxi medicinae". ${ }^{40}$ Similarly William Durstan and Roger Kemble testified in 1687 that Elias Scobel had been found skilful not only in medicine but also in anatomy, pharmacy and botany "post varia examina". ${ }^{41}$ The theory examination was obviously the hard part for those lacking formal training, such as $\mathrm{Mr}$ Abraham Every. On his behalf in 1739 one Mr Geare wrote to the diocesan official noting that Every "hath done many great cures, but is wanting in the Theorie part". 42 Although licences were more frequently granted to applicants after 1740, as late as 1750 examinations were still being carried out. The application of Robert Goss of Wembworthy was signed by two surgeons, Robert Smith of Chulmleigh and George Marie Grossard of Hatherleigh, each separately making an explicit reference to the fact they had examined the said Goss. $^{43}$

If examinations were taking place, and if different approaches were being made in order to obtain a licence, it should be possible to say something about those who were turned down. For a start one can say a brief word about discrimination on grounds of sex. There are only ten applications for midwives in the collection of applications, and there is no indication that five of these were granted. Thus it seems likely that not only were very few successful, but that applications were positively discouraged. With regard to female practitioners of surgery, Exeter did in theory permit female practitioners, but in the period under study actually licensed only one. ${ }^{44}$ No petitions survive for female surgeons, and it seems likely that applications from women were discouraged for both surgery and midwifery.

Using the fact that most certificates of medical competence have fewer than five signatures and communal petitions by definition have more than this, it is possible to distinguish what sorts of approach yielded the best results in gaining a licence. Overall, 36 out of 131 extant applications with fewer than five signatures appear to have failed ( 27 per cent). By comparison, 21 out of 48 extant applications with seven or more signatures appear to have failed (44 per cent). The first category, of course, includes not only medical certificates of competence but also those certificates of good behaviour signed by clergymen, and combined certificates. Restricting these solely to those certificates signed by known medical practitioners, and only by them, a more striking figure emerges. A maximum of 8 out of 47 applications appear to have failed (17 per cent), and, given the known under-recording level, this is almost certainly an exaggeration. Thus it can be seen that an application

\footnotetext{
${ }^{40}$ DRO: Moger II/surgeons' licences/Devon/ Unplaced.

${ }^{41}$ DRO: Moger II/surgeons' licences/Devon/ Unplaced.

${ }^{42}$ DRO: Moger II/surgeons' licences/Devon/ Cullompton.
} 


\section{Diocesan Licensing and Medical Practitioners}

supported directly by a certificate of medical competence was much more likely to succeed than an application with the backing of the local community and clergy, or with a series of testimonies from cured patients.

Certificates of medical competence other than those relating to examinations very often stress the credentials and qualifications of the applicant. From these we can build up a picture of the range of backgrounds from which licensed practitioners came. Joseph Lillycrap, aged twenty-three, having completed a local apprenticeship as a surgeon, is representative of the younger licentiates. ${ }^{45}$ To this category should be added those who had completed a year or two of formal training at a London hospital, ${ }^{46}$ or a seven-year apprenticeship with a London surgeon, ${ }^{47}$ or an apprenticeship split between Devon (three years) and London (four years). ${ }^{48}$ Eight candidates (4 per cent) were clergymen who had a university education and required a licence to assist them in their cure of bodies as well as souls. Several seventeenth-century applicants had served in the recent wars or had a military surgical training. ${ }^{49}$ One licensed candidate in this period-the notorious Nathaniel Eaton-already had a medical doctorate from Leiden, ${ }^{50}$ and an apparently unsuccessful applicant, Gray Holland, already had a MB ${ }^{51}$ A significant number had spent time assisting in the practices of kinsmen. ${ }^{52}$ But the most notable and common qualification is that applicants had "for many years practised the art". In the diocese of Exeter, practitioners' pre-licensing careers could be just as long as the twenty or thirty years noted in respect of practitioners in other regions: ${ }^{53}$ William Tucker had "byn a practitioner of physsick ... for the space of fforty yeares upwards". ${ }^{44} \mathrm{Mr}$ James Bush was "of above thirty years successful practice". 55 Rice Morris had "been a practitioner of the Art of Chirurgery this twentye years" ${ }^{56}$ Many stress periods of experience in excess of ten years. While long service was the easiest distinction to claim and the hardest to disprove, and therefore perhaps should not be taken at face value, these applications point to a significant proportion of licensed practitioners being older men from diverse backgrounds. A medical licence therefore

\footnotetext{
${ }^{45}$ DRO: Moger II/surgeons' licences/Cornwall/ Falmouth.

${ }^{46}$ DRO: Moger II/surgeons' licences/Cornwall/ Liskeard (John Lyne).

${ }^{47}$ DRO: Moger II/surgeons' licences/Devon/ unplaced (Edward Manninge).

${ }^{48}$ DRO: Moger II/surgeons' licences/Devon/ unplaced (Anthony Norris of Inwardleigh).

${ }^{49}$ For example, Mr George Trewicke had served an apprenticeship in "His Majesty's Hospital at Plymouth for sick and wounded seamen and prisoners of the late war"; in 1667 John Stavely claimed service "in the late engagements" to his credit; and William Wyatt "served as chirurgeon att sea in his voyages to the Straights and other places, as chirurgeon to a regiment of foote and also as chyrurgeon to their Majesties Hospitall at Plymouth”. (DRO: Moger II/surgeons' licences/Cornwall/Roche, and Devon/Kingsbridge and Plymouth.)

${ }^{50}$ DRO: Chanter 44; John Venn, Alumni Cantabrigienses, Cambridge University Press, 1922-54.
}

\footnotetext{
${ }^{51}$ DRO: Moger II/surgeons' licences/Devon/ unplaced (Gray Holland). His application was probably dismissed as unnecessary, as his services in examining candidates were called upon several times in subsequent years. He advanced MD by 1669 .

${ }^{52}$ For example, John Evans spent sixteen years practising under his father, "a professed and licensed surgeon"; John Tossell of Burrington spent three years apprenticed to his grandfather; and Peter Blackaller, son of an eminent Canterbury licentiate, Thomas Blackaller, stated as his qualification his upbringing and education in his father's household "for twenty years and more" (DRO: Moger II/surgeons' licences/ Devon/Kingsbridge, Burrington and Colyton).

${ }^{53}$ For other localities, see Harley, op. cit., note 5 above, p. 31; Hess, op. cit. note 5 above, p. 55.

${ }^{54}$ DRO: Moger II/surgeons' licences/Cornwall/ Minster.

${ }^{55}$ DRO: Moger II/surgeons' licences/Somerset/ unidentified.

${ }^{56}$ DRO: Moger II/surgeons' licences/Devon/ Dartmouth.
} 


\section{Ian Mortimer}

Table 4

Involvement of medical graduates in the licensing process

\begin{tabular}{lcccccc}
\hline Date & $\begin{array}{c}\text { No. of } \\
\text { applications }\end{array}$ & $\begin{array}{c}\text { No. of medical } \\
\text { signatures } \\
\text { identified }^{1}\end{array}$ & $\begin{array}{c}\text { No. of med. } \\
\text { sigs per } \\
\text { application }\end{array}$ & $\begin{array}{c}\text { No. whose } \\
\text { qualifications } \\
\text { are stated }\end{array}$ & $\begin{array}{c}\text { No. with } \\
\text { MD or MB }\end{array}$ & $\begin{array}{c}\text { Proportion } \\
\text { with medical } \\
\text { degrees }\end{array}$ \\
\hline $1661-1690$ & 65 & 79 & 1.2 & 55 & 30 & $55 \%$ \\
$1691-1720$ & 81 & 141 & 1.7 & 115 & 43 & $37 \%$ \\
$1721-1750$ & 33 & 74 & 2.2 & 68 & 14 & $21 \%$ \\
$1751-1780$ & 23 & 59 & 2.6 & 48 & 16 & $33 \%$ \\
\hline
\end{tabular}

${ }^{1}$ This is a total of all those who are described in a medical capacity, or who are known from other documents to have been medical men. It is an under-estimate of the number of medical individuals, as some practitioners who appear only once, without an epithet attached to their name, will not have been included.

should be seen not so much as relating to a specific learning path or qualification but as having a grounding in basic medical theory and a proficiency in certain arts, gained from a variety of sources. It purported to be a "kitemark": a symbol of trustworthiness, or an official endorsement.

The reliability of the licence as a symbol of trustworthiness or quality depended on the integrity of those acting as referees and examiners of new candidates. As mentioned above, a wide range of practitioners signed certificates of competence for one another. A total of 356 signatures known to be those of medical practitioners have been identified on the 202 applications 1661-1780. Of these 287 are known to have been MD, MB or licentiates (of one form or another, but mostly diocesan). The following table shows numerical evidence to support an observation made with regard to the licensing of midwives in the north-east, viz. that medical practitioners' involvement in licensing increased in the early eighteenth century. ${ }^{57}$ However, it also shows that, as the average number of medical signatories per application increased, the proportion of these in the south-west who held medical degrees declined. Thus it seems that, even before the 1718-20 watershed, licences were more frequently being granted as a result of medical authority than in the $1660 \mathrm{~s}$, and that this medical authority was being exercised not by medical graduates but by licentiates, most of whom were themselves diocesan licentiates, forming an increasingly distinct professional group of their own.

\section{The Politics of Licensing}

The above view of licensing as conveying a mark of official approval suggests a fundamental reason why a practitioner might seek a licence, but it is only one reason, and to suggest it was always the most important one would be an over-simplification. Furthermore, it is not a sufficiently full reason to answer the basic question: why, if

\footnotetext{
${ }^{57}$ Harley, op. cit., note 5 above, p. 31.
} 


\section{Diocesan Licensing and Medical Practitioners}

few practitioners had a licence and few prosecutions were brought against those practising without one, and many clergymen claimed not to know whether their local practitioners were licensed or not, ${ }^{58}$ did practitioners submit themselves to the trouble and expense of obtaining them? Indeed, what actually was their significance to their holders and the communities they served?

To begin with, but probably of minor importance, there was a straightforward legal and economic rationale to licensing. In theory no one could charge for medical advice or visiting without obtaining a licence to practise. ${ }^{59}$ Thus, by obtaining a licence a person also obtained freedom from worry about being called to account for practising without one. It is also possible that a practitioner obtained wealthier clientele, and very likely that he was able to charge more for his services. However, it would be wrong to apply these motives to practitioners who had practised for ten, twenty or thirty years, especially considering that in practice the rule of non-payment was not altogether followed. One 1750 applicant even went so far as to imply that he was already charging his wealthier clients, if not his poorer ones:

... and hath thereby cured $\&$ recovered divers $\&$ sundry persons of good ranke $\&$ quality besides an Innumerable company of other people of a lower degree of and from greate lingeringe and dangerous deseases $\&$ sicknesses $\&$ in so charitable a manner as that from the poore sort of people hee hath taken $\&$ receaved little or no reward att all for his paynes ... ${ }^{60}$

There was a more subtle legal and economic reason for obtaining a licence, which may be seen clearly through the case of Thomas Bryant, mentioned above. The certificate attesting to Bryant's capabilities as a surgeon is accompanied by a petition of Thomas Hoskyn, yeoman of St Brewer, Cornwall. This states that the petitioner's wife had been affected by a sore in her thumb for seven years, and, about two years earlier, one Thomas Bryant, a vagrant claiming first to be a hop-buyer and then to be a surgeon, gave her some black salve to put on it. This failed to work, but on his next visit he demanded twelve shillings for the treatment, possibly in part payment of a successful remedy. A disagreement ensued. Only then, it was claimed, did Bryant set about gaining a licence. According to Hoskyn, he bribed "an indigent decayed apothecary" 61 of Bodmin with a guinea to procure a certificate, with which he obtained a licence in Exeter. Bryant then took legal action against Hoskyn for non-payment of the twelve shillings. Clearly from Bryant's point of view, a medical licence afforded legal protection. Not only did it support his claim to be a good surgeon it also removed the risk he would lose his case by being found guilty of acting without a licence. If the latter had happened, he would also have been fined and prevented from practising again. This may well explain why a number of individuals with many years' experience sought a licence: they increasingly required the support of the law to enforce payment, or to

\footnotetext{
${ }^{58}$ See, for example, Guy, op. cit., note 7 above, p. 528. A local example also is that of William Cowan of Moretonhampstead, who was described as a licentiate when he signed a fellow practitioner's statement on 3 June 1704, but who did not apply for his own licence until 20 June 1704, seventeen days later.
}

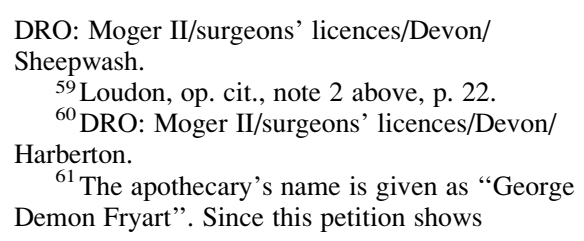




\section{Ian Mortimer}

provide a legal defence in case of being taken to court. Several other documents repeat this desire for legal recognition, or are letters addressed to the diocesan official on behalf of individuals in danger of being prosecuted. One such letter in particular requests "the protection of a licence to practice Physick" for a practitioner and bailiff of Dartmouth in 1689 , who

... by executing the precept for electing too Burgesses in opposition to too bad men [who] were like to be put upon us has enraged the gentry here to seek all occasions against him. And being engaged often to go beyond the bounds of his profession as an apothecary especially amongst the ordinary sort of people, I doubt should he not be licenced they will that way ensnare him. ${ }^{62}$

Clearly the legal threats to an unlicensed practitioner came from a number of quarters: from the gentry, aggrieved patients and rival practitioners, as well as the clergy and the triennial visitation.

It is of course necessary also to consider religious conscience as a motivating factor. This is especially so in the cases of clergymen, who perhaps felt more keenly than most the ecclesiastical requirement to be licensed if charging for services. But it is also important to consider the perceived effect upon the very process of healing. Rosemary O'Day has pointed out that the sixteenth-century concept of a profession as a striving to follow God's calling underpinned the skills of the "professions". ${ }^{63}$ With regard to medicine, this set the licensed practitioner at an advantage over the unlicensed: by obtaining a licence the practitioner was confirming his spiritual calling, and, if correct in assessing God's will, would inevitably benefit from cures effected through his love of God. Several seventeenthcentury applications stress that cures have been achieved "by Gods blessing on his endeavours", and the implication is that the practitioner has only been the instrument of Divine healing. ${ }^{64}$

The practitioner was not the only member of a community affected by religious conscience; his patients also were subject. In this way one can understand why the inhabitants of a locality, as well as the clergy, wanted a man of honest character and of sober life and conversation; to have put oneself in the care of a profligate loose-living practitioner would have been to jeopardize oneself twice over: first, under the practitioner's erring hand, and second, as the sacrificial victim of God's judgement upon his character. The fact that such hints of divine intervention in the healing process are stated overtly in seventeenth-century applications but not eighteenth-century ones helps to explain the shift in emphasis from religious signatories to medical ones, and the decline in numbers of licences sought and issued during the Enlightenment.

It would be wrong, of course, to try and explain the licensing of medical practitioners in terms of economic, legal and religious motives, and neglect what is arguably the most important aspect of all, medical proficiency. As with religion, this offers two opportunities

\footnotetext{
Hoskyn to have been hoodwinked time and again, this might not be the genuine name of a genuine apothecary.

${ }^{62}$ DRO: Moger II/surgeons' licences/Devon/ Dartmouth.

${ }^{63}$ Rosemary O'Day, The professions in early modern England, 1450-1800, London,
}

\author{
Longman, 2000, especially ch. 2, pp. 18-43. \\ ${ }^{64}$ See, for example, DRO: Moger II/surgeons' \\ licences/Devon/Hennock and Harberton. The \\ application of John Colwell of Harberton also stresses \\ that for eight years he had followed the "practice and \\ calling" of a physician.
}




\section{Diocesan Licensing and Medical Practitioners}

for examination: the medical role of the practitioner as an individual with a service to sell, and the role of the community in purchasing that service.

As David Harley has remarked, "Any effective system of medical licensing limits competition between practitioners by restricting entry into the market and punishing interlopers". ${ }^{65}$ Punishment of interlopers has already been discussed, but the question of "restricting entry into the market" requires further expansion. Religious preferences have been mentioned above. Other market restrictions probably were directed most heavily at strangers; and it has to be noted that many practitioners settled in parishes far from where they grew up. Thus licensing was desirable in cases such as that of Mr Jonas Griffin, who had been in Dartmouth for about four months when he applied for a licence to practise physic there. Surgeons qualified in the navy and army also may have settled more easily into a community if they were known as a licensed practitioner, fulfilling a preconceived and commonly understood role. This also applies to licences to practise throughout the diocese, obtained by itinerant practitioners who chose to travel through the two counties. Most of all, however, it seems that recognition as "skilful" was principally sought by the practitioner. As has been shown, a licence implied that its holder had undergone a process of examination or certification. The sense of "merit" in holding a licence is borne out by some community petitions, such as that on behalf of Michael Hobbs of Fowey, written by the rector in 1662, which states "so that (as we conceave) his good ... skill and abilities may very well merritt licence for the Administration of Physick". This also suggests why Abraham Harward obtained a certificate of medical competence, signed and sealed by two practitioners, in 1659, when the diocesan system was not functioning. ${ }^{66}$ The most logical explanation of Harward's action is that a certificate of competence was by itself seen to be a distinction. ${ }^{67}$ Even if the holder of a licence was actually incompetent, the important aspect is that he was still seen to be recommendable, and thus could justify charging more for cures, or for taking on an apprentice. The fact that "the range of the irregulars was very wide and they shaded off imperceptibly into the regulars" 68 exactly explains the purpose of a licence and why licences continued to be sought for so long; licentiates could number themselves among the ranks of those with official approbation, as opposed to the quacks with whom they might otherwise be associated.

Elitist implications of licensing suggest one reason why members of the gentry and other responsible local men made concerted efforts to stop certain practitioners from obtaining licences. ${ }^{69}$ Just as interesting are the very positive attempts to obtain licences for certain practitioners by communities. The form of testimonial best described as a communal petition, signed by a number of substantial members of a community, including the mayor and clergy,

\footnotetext{
${ }^{65}$ Harley, op. cit., note 4 above, p. 398.

${ }^{66}$ DRO: Moger II/surgeons' licences/Cornwall/ Morwenstow. Sealing was the method used also by examiners of practitioners in physic in Plymouth in the 1660 s.

${ }^{67}$ It seems Harward did not submit this document to the ecclesiastical authorities for a few years, and was granted a licence only in 1675 .
}

\footnotetext{
${ }^{68}$ Loudon, op. cit., note 2 above, p. 17.

${ }^{69}$ See, for example, DRO: Moger II/surgeons' licences/Cornwall/Launceston (letter from John Ruddle to Francis Cooke, 1673), and Moger II/surgeons' licences/unplaced (letter from Dr Oxenden to Mr Cooke, 1699).
} 


\section{Ian Mortimer}

churchwardens, constables, gentry and sometimes other practitioners, has been mentioned above as more frequently being turned down than accepted as a certificate of medical competence, and as more often resulting in a geographically limited remit, but it may be seen as the most forceful attempt to use licensing as a form of parochial control of practitioners. Many of these petitions, testimonials and certificates were written by the rectors, vicars and mayors of the towns in which the applicant was resident. ${ }^{70}$ For example, one 1706 petition begins "We the Mayor of the said Towne together with the Ministers churchwardens and other the choice inhabitants and also the gentlemen of the neighbourhood whose names are subscribed". ${ }^{71}$ That of Edward Chenhall is even more significant. Chenhall had

... at all times been ready to use his utmost endeavour and skill in order to [obtain] our relief in which he hath been blessed with uncommon success, and restor'd great Numbers from extreme misery to perfect Ease. But finding ourselves likely to be depriv'd of his great usefulness by the malice of some who we hear would prosecute him for his good services to us and the poor in our neighbourhood and your petitioners living very remote from any other helps of the like kind, and believing it would be for the Comon good if the said Edward Chenhall had liberty to act in this capacity more freely ... [we ask that you] grant [him] ... a licence to practise chirurgery. ${ }^{72}$

If the several cases of communities applying for a licence on behalf of a specific practitioner are to be taken at face value, and there is no reason why they should not be, they suggest that the licensing system was used by local authorities as a safeguard against unapproved practitioners. They could prevent their community being visited by itinerant quacks, or, if they did visit, they could deprive them of the right legally to practise without jeopardizing their established medical service. What is particularly interesting is that this appears to have happened in large towns as well as in the small ones. The mayor of Plymouth headed the list of signatories of one such petition in 1715, and the mayor of Okehampton submitted one in 1665. In these towns the emphasis may well have been on favouring particularly well-connected practitioners or those who were acting on behalf of the poor of the town. ${ }^{73}$ A number of petitions stress the numbers of poor people cured, and a town's action in effectively appointing its principal physician or surgeon helped not only to secure the services of a trusted practitioner but at the same time established an exclusive market for his services.

Another interesting fact about this method of applying for a licence is that it was in decline throughout the period in question. As Table 5 shows, the majority of these petitions date from the decade after the Restoration. Thus the involvement of local communities in the licensing process appears to have been strongest at the same time as the involvement of medical degree holders. This seems to be a conflict of

\footnotetext{
${ }^{70}$ See, for example (in addition to those quoted in the text), the petitions for the parishes of Tiverton (1689), Great Torrington (1685-6), Dartmouth (1724), Colyton and Seaton (1697), and Winkleigh (1705).

${ }^{71}$ DRO: Moger II/surgeons' licences/Cornwall/ Marazion.
}

\footnotetext{
${ }^{72}$ DRO: Moger II/surgeons' licences/Cornwall/ St Martin in Meneage.

${ }^{73}$ For examples, see DRO: Moger II/surgeons' licences/Denbury, Winkleigh, Hennock, Harberton.
} 
Diocesan Licensing and Medical Practitioners

Table 5

Petitions among applications for licences, 1661-1783

\begin{tabular}{|c|c|c|c|}
\hline Date $^{1}$ & $\begin{array}{c}\text { No. of extant } \\
\text { applications (a) }\end{array}$ & $\begin{array}{c}\text { Number of extant } \\
\text { applications granted with } 6 \\
\text { or more signatures (b) }\end{array}$ & $\begin{array}{l}\text { Proportion of } \\
\text { petitions }(b / a)\end{array}$ \\
\hline $1661-1675$ & 54 & 24 & $44 \%$ \\
\hline $1676-1690$ & 11 & 1 & $9.1 \%$ \\
\hline $1691-1705$ & 42 & 10 & $24 \%$ \\
\hline $1706-1720$ & 39 & 11 & $28 \%$ \\
\hline $1721-1735$ & 13 & 5 & $38 \%$ \\
\hline $1736-1750$ & 20 & 1 & $5 \%$ \\
\hline $1751-1765$ & 17 & 0 & $0 \%$ \\
\hline $1766-1780$ & 6 & 0 & $0 \%$ \\
\hline 1783 & 1 & 0 & $0 \%$ \\
\hline Total & $203^{2}$ & 53 & mean $=26 \%$ \\
\hline
\end{tabular}

${ }^{1}$ Undated documents have been dated by the date of the grant to which they relate, or, in the few cases where this has not been possible, by the mid-point of a date range suggested by other data, for example, the period of office of the bishop to whose authority the document was submitted, the reign or the king, or a period established by the names of signatories (where these are other practitioners, clergymen or mayors).

${ }^{2}$ This table does not include the 1659 certificate for Thomas Harward, made before the licensing system was restored.

interests-locality against expertise-until one reflects that this is also the period when the greatest proportion of licence applications was turned down. As a result, one may interpret the evidence of Table 5 as showing the declining influence of local communities, similar to the declining influence of university-trained practitioners mentioned above.

\section{Conclusion}

The history of medical licensing by diocesan authorities deserves far more detailed study than it has hitherto received, especially with regard to practitioners of medicine. Despite some methodological problems, changes in the number of licences sought and granted can be traced, and a wealth of detail may be drawn out about provincial communities, which are otherwise difficult to study systematically with regard to medicine. In the diocese of Exeter it is clear that the licensing system underwent fundamental changes over the period in question, and while one may debate the relevance of such procedural factors as visitations, nevertheless, the geographical control of practitioners in the late seventeenth century and the simultaneous decline in the religious aspects of licensing are both clear. Equally clear is the decline in importance of two social groups: university-trained practitioners and local social élites. These groups lost influence to the licentiates themselves, and one might suggest that the reason was the same: a growing 


\section{Ian Mortimer}

specialization of medical ability among the emerging surgeon-apothecaries. What is certain is that, even in its last decades, the system was able to adapt. No study of medical professionalization can be considered complete if it ignores the development of the types of licences granted by the church, and the more professional way in which licences were sought and obtained in the eighteenth century. 